Int.J. Hum. Soc. Dev. Res.

ISSN (P):2521-1439; ISSN (E):2523-4331

Volume 1, Number 2, 2017. 53-64

DOI: $10.30546 / 2523-4331.2017 .1 .2 .53$

\title{
YORUBA ORAL FABLES AS ARTICULATION OF CULTURAL ETHOS
}

\author{
Rabiu IYANDA \\ Osun State University, Osogbo, Nigeria
}

(C) The Author(s) 2017

\begin{abstract}
Literature remains a vast field where many issues concerning human beings and her relations to others, both human and non-human are identified and solved. This paper looks at how fables have assisted in preserving and regurgitating cultural ethos in the Yoruba community of Nigeria. Fables which used to be so popular and common phenomenon is nowadays becoming a rare name in society. Technological inventions which have taken the place of this literary genre in society could be positively utilized for advancing the course of fables. The paper identified some problems militating against fables and some plausible suggestions are proffered to forestall untimely departure of this important and useful literary element across societies.
\end{abstract}

(C)2017.All rights reserved

\section{ARTICLE HISTORY}

Received: 21/02/2017

Accepted: 28/07/2017

Published online: 05/10/2017

\section{KEYWORDS}

Animals, Audience, Fables,

Cultural ethos, Yoruba 


\section{Introduction}

Literature is an imaginative work of arts representing happenings in a society and uses language to embellish its content. It could be said to originate with the creation of man, as it dwells into man activities in all ramifications of his/her existence. Literature is not only an imitation of life, but also a concept which derives from certain sustainable principles. Literary work or literature could be appreciated partly from the way it uses language to deliver the literary aim.It emanates from members of a society narrating or retelling the happenings of such a society. Literature could be seen as a work of art that reflects the total being of a man in life.

Ukande $(2012,91)$ opines that;

○ Novel, (a literary form) for centuries, has been readily made available as a tool

$\circ$ in the hands of literary artists, which they use to x-ray the odds of the society

$\circ$ in a cogent and realistic manner.

It beholds any good literary writer to unravel the happenings in his environment. Happenings in societies dictate topic of discussion for writers. It is the function of any literary writings or narrations, to awaken social consciousness in the audience. It also serves as agent of satire by exposing the exploiters and the oppressed in any human society. Literature of any kind, oral or written, portrays a close imitation of life, it remains an agent of mediating for the well-being of the society at large. Literary recreations of local beliefs are available in oral form and later transformed into written. It condemns the vices and commends virtues in the society. The example of Fable de la Fontaine, written by Jean de la Fontaine during the era of Louis $\mathrm{XIV}$, in the French history of the XVII century is a good one. NineteenEighty-Four, George Orwell, is another example of literary writings that stands the test of every time in human history, though written to satirize the bourgeoisie class in the English literature of 1948. The content of 
oppressing one another among human being seems to be unavoidable in any human gathering. As writers and narrators expose such societal ills, such accomplishment will help to forestall such attitudes and pave way for positive change. In the oral narration as well, the narrator engages in the act to impact morals in the audience which are usually always young ones in the society.The story is narrated to preserve and portray the customs and principles of such a society. The young ones are made to deduce meaning from the resultant effects of a particular hero in any narration. The end of such an oppressor, thief, burglar, exploiter, tyrants serve a lesson to the audience. They try to avoid such a catastrophe end in their own journey of life.

The written form of literature is usually present in the absence of the author and the writer claim ownership. In the case of the oral literature, it belongs to the society, no person claims its authorship as it grows with the society and being passed orally from one generation to the other.Literature generally has various genres, which could be rendered orally, the primary form of communication and in written form, the secondary form. Fable, an aspect of literature, remains a useful instrument for impacting morals and preserving cultural decorum across societies. It thrives before the advent of technological developments and survives many difficulties. Among the major roles it plays in the pre-technological era is entertainment, moral uplift and cultural preservation.

\section{Effects of foreign contacts on the Yoruba}

Yoruba refers to a group of cultures linked by a common language. They occupy an area bounded by the Niger River, and including what is now known as the southwestern Nigeria, and part of the Republic of Benin and Togo. They share the same socio-cultural belief system. They also held much conviction in their ancestors and traditional religions. The original religion, traditions and cultures of the Yoruba like all other people of Africa have been declining over the past century as a result of influences of interventionism by the white, Western acculturation and sweet-talking by Christianity and Islam. These factors affect negatively the standards of 
living of the Yoruba. The Yoruba, much cherished culture could no more be properly recognized, it has been contaminated by the western cultures. The western cultures now wrongly influence most of their daily life and constitute nuisance in their communities. The natural, socio-cultural and political atmospheric conditions and religions are no more the same. Their principles and value of judgement have been altered.

The much cherished and effective ways of impacting knowledge and sustaining their cultural ethos are no more recognized. Their cultures are now less protective, thereby foreign cultures overrule, creating nonconducive atmospheric conditions. The western cultures should not have been allowed to sweep the long-age traditions. To borrow from other cultures such an aspect that will not constitute a nuisance to one's ways of life is not condemned, but the existing norms should be allowed to thrive. It would havebeen an added advantage and better for the Yoruba to be concerned with the traditional ways of imparting knowledge, educating and preserving their cultures before the influx of foreign intervention, religions, technological and several other modern and strangeinventions. The modern ways of life learnt through cultural contacts should be considered an advantage to better some areas of living. The technological discoveries could also serve as an added avenue to promulgate their traditions. It will be a good instrument for preservation and could also assist in disseminating same across people in distance places. The idea of jettison fables to foreign films given room to the appreciation of such strange cultures should not have been given priority over the cherished African manners of living and sustenance.

\section{Brief about Fables}

Fables serve as an informal way of educating the younger ones of the customary manners of behaving in different situations. It remains a useful factor in educating the young ones and to preserve the language, culture and literature of a society. A fable is a literary genre which takes the form of a short allegorical tale and intends to convey a moral lesson.Fables 
could be perceived to be children's stories which feature animals as characters, with the ability to speak and act as human. Fables are stories meant to teach morals or useful lessons to develop the child into achieving a balanced life in the future. The device used by the narrator include power of captivating the minds of the child to listen, to learn and to retrieve easily. Availing the audiences of interesting narratives boost linguistic capacity of the listeners and that of the narrator.

Animals that serve as the characters in fables act and speak like humans. These animal-characters in fables are made to engage in human individualities in an attempt to teach, correct or to satirize human attitudes. Akporobaro $(2006,46)$ opines that a folktale or fable is a traditional story which is told for entertainment and not meant to be believed and handed down either in written or oral form. It is a brief succinct story that features anthromorphized animals, plants, inanimate objects, or forces of nature that illustrate a moral lesson with the aid of human language.

In a more concise form, a fable is a narrative form, usually featuring animals that behave and speak as human beings, told in order to highlight human follies and weaknesses. A moral lesson for behaviour is woven into the story and often explicitly formulated at the end.

Fables are prepared to serve children as audience, readers, or participants. The primary aim is to stimulate rapid development of the child's creative and intellectual abilities.

Fables plays the following dominant roles among others in any human society;Relaxation and enjoyment; equip the audience usually children with the cultural experiences; to understand the people more and be able to relate with people around them; getting solutions to life complex problems; inculcate moral and transmission of cultural values in the younger ones; develop in the children the ability to adapt to the changing environment. 


\section{Fable as agent of cultural preservation}

In the Yoruba society, fables play a dominant role in preserving their cultural ethos. In fables younger ones are made to realize the reason for many things in their society. Fables are narrated and the children are to look for the hidden meaning after the narration. Fables are not just stories for whirling away time but stories meant to teach morals or useful lessons to develop the child into achieving a balanced life in the future. Fables are used particularly for the power of captivating the minds of the child to listen, to learn and to retrieve easily. The following fable reveals how to maintain peace, unity and development.

\section{The tortoise and the cricket}

Once upon a time, tortoise and cricket ware intimate friends. They did things imitating each other. As time went, there was a famine in the town. The famine brought hardship to the entire people. As for the cricket, it did not feel this famine so much. Yannibo the wife of tortoise geared its husband to look for ways of feeding the children. She lamented that the friend, cricket, did not feel the famine, why then are you friends? So, lamented the wife. This irritated tortoise and made him decided to go to its friend's house. Tortoise woke up from its own place of abode one day and went to cricket's house.

'My friend, cricket, why have you been deceiving me since?' he said. My family could not eat since and everybody in this our surroundings know us as comrades. You are healthy, robust and feeling fine, please, do tell me how you manage to get food, said the tortoise. For cricket, she knew the character of her friend that it behaved in a tricky manner. She promised to reveal the secret to her friend on the next day.

As early as possible the next day, tortoise went to meet its friend and discovered how to eat in this period of hardship. To the cricket, it should not be a thing of joy for a friend to suffer while another enjoys in abundant 
pleasure. It then gave a note of warning to her friend that the secret should not be a thing for the public. She took tortoise to her farm under the rock. Before the rock could give way for any entrance there was a song. Cricket sang a song. As the song was rendered, the rock paved way for the duo. The manner the rock paved way was very shocking to tortoise, but he did not demonstrate any indication of this. They entered, cricket uprooted yam for her friend to take home for its family. Before leaving, she considered it necessary for them to eat. She then cooked yam for them to eat. Tortoise asked for something to use for eating the yam, the cricket, granted to satisfy her friend. She asked the friend, tortoise, to put her in the cooking pot, put the pot on fire and render a song. As she rendered this song, the cricket started to generate oil. The oil was then used to eat the cooked yam to satisfaction. This really made tortoise to feel relaxed and undisturbed. They both returned to their different houses with baskets full of yam.

Some days later, Tortoise informed his family of a farm he had just acquired and promised to lead them to this farm. The appointed day came and Tortoise and his family set out to the farm. On getting to the same place, the family looked baffled seeing the entrance. Tortoise knew well the song rendered by his friend, cricket, he started the same song. The rock paved way for them, the tortoise and its family entered successfully. As the owner did, tortoise replicated and all worked well for him. He then thought of feeding its family before leaving for home. They boiled yam, and looking for something to eat the yam. Tortoise asked its children to put him in the pot as did the cricket, the children obliged to this instruction of their father, tortoise in the frying pan, fire under it with the song. The song continued for some time, but instead of producing oil, tortoise was boiling and he died in the red-hot pan.

Efforts to get out from this cave became another problem for the yannibo and the children. As they pondered over this, cricket entered. They explained what had happened to them in a disgraceful manner, the death of tortoise and the unproductive efforts of getting out of the trap. Cricket did not see any reason why a traitor should be pitied; she repossessed her yam 
tubers and took all of them to the palace. In the palace, they were all killed as the law of the land forbade stealing of any kind.

\section{Moral instructions from the fable}

This fable exposes farming as a major profession in the area. They engage in farming. Farming is the solution to famine. In any society where people are not ready to toil the land, food shortage is imminent. Cricket farms and was able to feed its family even during food shortage of which many are unable to feed. Tortoise was lazy and its family are made to suffer. Despite the lazy attitudes of tortoise, it made efforts to feed its family at all cost. This led him to begging its friend, cricket for food to feed its family. This act, begging, was considered inappropriate in the Yoruba society. When its friend, cricket agreed to assist, tortoise misuse the opportunity. Greed and stealing result in untimely death. From the fable it is evident that we should desist from such attitudes: laziness, begging, dishonesty, and stealing.

Looking at the present situation of societies, these problems identified in the fable above constitute the bane of societal ills. Fable could be used to reduce or eradicate such a menace in our societies.

Divorce could be perceived nowadays across societies. It is so rampant.This may be partly due to non-adherence to the laid down cultural ways of getting married. The pattern of dating, before marriage is structured and if properly followed, the cases of divorce may be drastically brought to minimum. The following fable serves as an example.

\section{Ajihun and Snake}

Once upon a time, there lived a farmer with his wife, Ajihun. They lived in a village. They planted yam, maize and plantain. This man was also a hunter, just for him and the wife. He did not sell any animals killed. He gave to neighbours. This makes the community to respect him for this 
generosity. They gave him a pseudonym, 'Sooresa', meaning giver of all time. This man has only a daughter with his wife. They visited many herbal houses, both far and near. All resulted the same. The efforts of this couple to have other child proved abortive. They adored the only child considerably. They pampered her and did not allow anything to affect this lady. As years passed, this lady became matured and time for her to get married. These parents awaited their daughter to come with her suitor as all those proposed to her was rejected. She gave one reason or the other as excuses. Many reasonable and well-meaning people in the town proposed to marry this lady, but to no avail. She continued to see one negative thing or the other in almost all. She aimed and promised to marry the wealthiest person. Her parents frowned at this greed nature of their daughter and they used to tell her the implications of such a notion.

One market day, this lady was on an errand to the market. She saw a very handsome man in the market. This man dressed elegantly and modestly. The man was a stranger as nobody could identify the face. This did not allow the man to be disturbed by any pleasantries or greetings. This lady was so moved and called this man. The man refused to answer. Everybody started to look at her and where she might have known this stranger. This lady, so moved, followed this stranger with all seriousness. This man rushed to avoid this lady, she doubled her efforts. At last she met the man and expressed her feeling for the man. The man warned this lady that he is not from that community. She insisted to follow him to his place of abode. This she did. They left the town and followed a part leading out of the town by foot. This man stopped and warned this lady that he is not from that town and his place is too far, he advised the lady to return to her parents. She insisted and asked the man to continue that she will follow him to wherever he lives. They entered a forest and crossed many streams, this lady continued to follow the man. As a final point, they got to a very large river. She requested the man to carry her to cross the river. This man carried the lady and they both entered the water. They finally arrived at the bottom of the river, this is where the man lives. The lady was so frightened but cannot go back. The man transformed to a very big snake. This frightened this lady the more. She cannot go anywhere. She then became the wife of a 
snake. The snake will hunt for them to feed and they both lived together till date in that place.

The lesson derivable from the story is morally suitable for many ladies of nowadays. Many of them are after the prosperous ones. Some adore beauty and sugar coated mouth. They marry affluence at the expense of their good livelihood. Many ladies do not allow their parents to have any saying in their marital matters. They consider these parents as being old and could not determine their suitors/ husband. This folktale also shows the Yoruba perception on marriage, they cherish to marry within their culture. This allows them to have an in-depth history of the supposed husband of their daughter and the family they will build. It also allows them to control and retain their norms and values. The cultural perception on this could be clearly seen and the consequences attached to the culprits is faced by this lady. A known worthy family is cherished while any family with bad image is not to be one's relation. When a marriage is successful, it bears positive effects and when unsuccessful, it contributes negatively to the society. It then becomes imperative to control societal standards through marriage.

\section{Conclusion}

The paper shows how fables have contributed to the retaining of cultural traditions in the Yoruba society in particular. The functions are not limited to this particular tribe but could be seen in every other human milieu. The importance and roles it played, how fables are used to impart and preserve artistic tenet. Fables in schools have assisted the younger ones on how to be a respected member of his/her community. The aesthetics and language in use fable narration help in retaining the attention of the audience. Over ages and across societies, fables constitute avenue for teaching the younger ones the rules governing the ethics and etiquettes of their community thereby preserving the cultural etiquettes and passing the same to generations. Restoration of fables will help revitalize comportments and reinvigorate the cultural standards of each society. This could be incorporated in the school curriculum at the lower levels of education. This 
will not only influence characters positively, but will assist the comprehension ability of these children. It will also be an avenue to develop the reasoning aptitude of the young ones and the judgement capability. Development can only be achieved under a conducive atmospheric condition, fables teaching of morals will help in achieving this goals. Fables could be documented with technological apparatus thereby the younger ones could have the opportunity of listening to it at their own leisure period instead of the foreign obnoxious videos.

\section{Disclosure statement}

No potential conflict of interest was reported by the author.

\section{Contact Information}

E-mail: rabiu4iyanda@gmail.com 


\section{References and notes:}

Akporobaro, F.B.O. 2006.Introduction to African Oral Literature.Lagos. Princeton Publishing Company.

Bergmann, P.G. 2007. Globalization. The new encyclopedia britannica. Docklands: Encyclopedia Britannica. 304.

Clayton, E. 2008. Aesop, Aristotle, and animals: the role of fables in human life. Humanitas. Xxi.1:179-200.

Hornby, A.S. 2015. Oxford Advanced Learner's Dictionary of Current English. Oxford : Oxford University Press.

Jean-Luc. 2008. Les fables peuvent instruire les hommes. Paris: Hâtiers.

Lester, H. 2007. Philips' encyclopedia comprehensive edition, London: Octopus Publishing Group.

Obinaju, J. N. 2008. Literature: the gateway to a fulfilled human experience, twenty-first inaugural lecture, University of Uyo.

Ukande, C. K. 2012 The novelist as a moralist: a eulogy of George Orwell's NineteenEighty-Four in Benue Journal of Languages and Linguistic Studies, Markurdi. The Returns Press Ltd.

Webster's 2013. The New International Webster's Comprehensive Dictionary of the English Language. Encyclopedic Edition. USA: Standard International Media Holdings. 